\title{
THE "DECENT BURIAL" OF PATENT LICENSEE ESTOPPEL
}

In I845 a patentee granted to licensees the right to manufacture a machine for ginning cotton and wool and received in return a right to a pereentage of their profits. The licensees breached the contract and claimed, as a justification, that the patent was invalid. ${ }^{1}$ The Supreme Court held that the licensees were estopped from asserting this defense, ${ }^{2}$ thereby establishing the doctrine of licensee estoppel. In June 1969, the doctrine was repudiated in Lear, Inc. v. Adkins. ${ }^{3}$ This note will briefly explore the doctrine, the rationales offered to support it, and the exceptions created to bypass it. An examination will then follow of the Lear case and its possible influence on future patent agreements.

\section{Estoppel Prior to Lear, Inc. v. Adkins}

Estoppel has most often arisen in two distinct but closely related situations involving the transfer of patent rights-estoppel of an assignor and estoppel of a licensee. ${ }^{t}$ In the assignment of a patent the inventor ostensibly transfers to the assignee all rights under his patent, retaining nothing for himself save the right to receive royalties. ${ }^{5}$ If after the assignment the inventor commences or continues to manufacture the patented device, he presumably is guilty of infringement, and his assignee is given a federal cause of action against the inventor. ${ }^{6}$ Numerous federal courts have held that the inventor may not defend on the basis that his invention was invalidly patented. ${ }^{7}$ A patent license, however, is a transfer to another of a limited right under the patent to manufacture, use, or sell the patented device at a prescribed royalty, free from a claim of infringement by the inventor. ${ }^{8}$ The inventor retains title to the patent

1. Kinsman v. Parkhurst, 59 U.S. (18 How.) 289 (1855).

2. Id. at 293.

3. 395 U.S. 653 (1969).

4. Assignee and licensor estoppel cases have arisen less frequently. See, e.g., StubnitzGreene Spring Corp. v. Fort Pitt Bedding Co., 110 F.2d 192 (6th Cir. 1940) (lieensor estoppel); Brown v. L.V. Marks \& Sons Co., 64 F. Supp. 352 (E.D. Ky. 1946) (assignee estoppel).

5. See 4 A. Deller, Walker on Patents $\S 335$ (2d ed. 1965) thereinafter cited as DeLLeR].

6. 35 U.S.C. § 271 (1964).

7. See, e.g., Faulks v. Kemp, 3 F. 898 (C.C.S.D.N.Y. 1880).

8. See 4 Deller $\S 381$. 
and may retain the right to manufacture, sell, or license the patent to others. A patent license is a contract, and a cause of action thereunder will normally arise under state law if the licensee breaches by nonpayment of royalties. ${ }^{9}$ In the past, courts have refused to permit a licensee to assert the invalidity of the licensed patent when he is sued for nonpayment of royalties..$^{10}$

Real property law served the courts well as a rationale for the estoppel doctrine." A grantor conveying property by deed is estopped from claiming any title inconsistent with the deed or from denying a material fact in the deed.$^{12}$ Analogously, if one conveys a potential right to exclude the public from an invention, he is prevented from derogating from the transferred title by claiming patent invalidity.$^{13}$ Similarly, when a landlord leases property and puts the tenant in possession, the latter is estopped to deny that the landlord had good title in a suit for rent. ${ }^{14}$ Under the same rationale, a licensee was prohibited from asserting patent invalidity in a suit for royalties under a licensing agreement. ${ }^{15}$ But just as an evicted tenant could contest the validity of the landlord's title in an action for past rent, ${ }^{16}$ the courts held that a licensee could test the validity of the patent in a suit for royalties where he showed an "eviction," such as a prior judgment of invalidity of the patent at issue..$^{17}$

By invoking the estoppel doctrine, courts have sought to prevent unfair dealings between the parties. Thus in one case involving a licensee's denial of the validity of his licensor's patent, the Court held that after entering into the agreement and manufacturing under

\footnotetext{
9. Id. $\S 380$.

10. See, e.g., United States v. Harvey Steel Co., 196 U.S. 310 (1905).

11. See Treece, Licensee Estoppel in Patent and Trademark Cases, 53 Iowa L. Rev. 525 (1967).

12. See 6 R. Powell, ReAl Property § 937 (1969).

13. See, e.g.. Westinghouse Elec. \& Mfg. Co. v. Formica Insulation Co., 266 U.S. 342, 350 (1924).

14. See, e.g.. Goode v. Gaines, 145 U.S. 141 (1892).

15. See, e.g., Barber Asphalt Paving Co. v. Headley Good Roads Co., 284 F. 177 (D. Del. 1922).

16. See, e.g., Merryman v. Bourne, 76 U.S. (9 Wall.) 592 (1869).

17. See, e.g., Drackett Chem. Co. v. Chamberlain Co., 63 F.2d 853, 854 (6th Cir. 1933). The assignce of certain patents licensed the right to use the patents in the grocery trade to licensee. Both the assignee and licensee joined in an infringement action against a third party, and the court found that the patent was invalid. It was then held in a suit for royalties by the assignee against the licensee that the previous judgment constituted the eviction, relcasing the licensee from his obligation to pay royalties. Id. See also White v. Lee, 14 F. 789 (C.C.D. Mass. 1882).
} 
it, a strong presumption arose that the claim of patent invalidity was made to avoid payment of the agreed upon royalties. ${ }^{18}$ This rationale was present also in the majority opinion by Justice Holmes in United States v. Harvey Steel Co. ${ }^{19}$ where it was found unjust to allow the licensee to use the process introduced to him by the patentee and permit him later to claim invalidity, thereby allowing an escape from royalty payments. ${ }^{20}$ Similarly, in Faulks v. Kamp, ${ }^{21}$ when an assignor attempted to assert invalidity of the patent after assignment, the Court in order to reach a just result, found an implied warranty that the assignor had title to what he conveyed.22 Since they were primarily concerned with the equities of the contracting parties, these Courts neglectcd the public policy considerations inherent in the federal law of patents.

Several exceptions to the estoppel doctrine arose. ${ }^{23}$ As stated previously, the licensee was not estopped if he was "evicted." Another exception permitted an assignor being sued by his assignee for infringement to narrow the claims of the patent in question by evidence tending to show the state of the art, so long as this narrowing did not nullify the patent in an attempt to deny infringement. The Supreme Court, in Westinghouse Electric \& Manufacturing Co. v. Formica Insulation Co., ${ }^{25}$ reasoned that if the state of the art was not examined, courts would be deprived of the best means of measuring what the patent included. ${ }^{26}$

18. Eureka Co. v. Bailey Co., 78 U.S. (11 Wall.) 488, $491-92$ (1870). But see Handler, Antitrust: 1969, 55 CORNELL. L. Rev. 161, 186-88 (1970).

19. 196 U.S. 310 (1905). The patent holder entered into a contract with the government for the use of his patented process and later brought suit for royalties. The government asserted invalidity as a defense even though there had been no prior determination of patent invalidity.

20. Id. at 318-19.

21. 3 F. 898 (C.C.S.D.N.Y. 1880).

22. "[1]n justice [assignors] ought not to be heard to say that they had it not and did not sell it, and to be allowed to derogate from their own grant by setting up that it did not pass." Id. at 904. St. Paul Plow Works v. Starling, 140 U.S. 184 (1890), is often cited to support the same proposition, but in that case the lower court admitted evidence concerning the novelty of the patent, and this admission was not held to be error by the Court.

23. See Cooper, Estoppel to Challenge Patent Validity: The Case of Private Good Faith vs. Public Policy, 18 W. Res. L. Rev. I122, $1138-54$ (1967).

24. See note 17 supra and accompanying text.

25. 266 U.S. 342,351 (1924).

26.

[But] the result proved to be an anomaly: if a patent had some novelty Formica permitted the old owner to defend an infringement action by showing that the invention's novel aspects did not extend to include the old owner's products; . . . if a 
Courts further limited the estoppel doctrine where counterveiling public policy considerations warranted protection. In Sola Electric Co. v. Jefferson Electric Co. ${ }^{27}$ a licensing agreement stipulated that the prices, terms, and conditions of sale throughout the licensed territory should not be more favorable to the licensee's customers than those set by the patentee. The patentee sought recovery of unpaid royalties and an injunction to restrain subsequent sales not made in accordance with the contract. The Supreme Court held that the doctrine of estoppel was in conflict with the prohibitions against price fixing of the Sherman Act and refused to apply estoppel since the invalidity of the patent would necessarily render the agreement illegal. ${ }^{28}$ Similarly, the Court has also held that it would be against the policy of the patent laws to estop an assignor from asserting in an infringement suit the defense that the assigned patent was a copy of an expired one, since a patent becomes part of the public domain upon its expiration. ${ }^{29}$ Furthermore, the Supreme Court has declined to grant injunctive relief to enforce a contract wherein the licensee agreed not to contest the validity of the patent, reasoning that the public interest in eliminating worthless patents was as important as the patentee's interest in protecting his monopoly. ${ }^{30}$ These numerous

patent had no novelty at all, the old owner could not defend successfully since he would

be obliged to launch the direct attack on the patent that Formica seemed to forbid.

Lear, Inc. v. Adkins, 395 U.S. 653, 665 (1969).

But see Casco Prods. Corp. v. Sinko Tool \& Mfg. Co., 116 F.2d 119 (7th Cir.), cert. dented, 312 U.S. 693 (1940) (scope can be narrowed even if patent reduced to a nullity). See also Ball \& Socket Fastener Co. v. Ball Glove Fastening Co., 58 F. 818, 823 (1st Cir. 1893).

27. 317 U.S. 173 (1942).

28. "Local rules of estoppel which would fasten upon the public as well as the petitioner the burden of an agreement in violation of the Sherman Act must yield to the Act's declaration that such agrcements are unlawful, and to the public policy of the Act which in the public interest precludes the enforcement of such unlawful agreements." Id. at 177. See also MacGregor v. Westinghouse Elec. \& Mfg. Co., 329 U.S. 402 (1947); Edward Katzinger Co. v. Chicago Metallic Mfg. Co., 329 U.S. 394 (1947). Here the licensors sought only to collect royalties but the Court held that the existence of the price fixing clause was enough to bring the validity of the patent into question.

29. See Scott Paper Co. v. Marcalus Mfg. Co., 326 U.S. 249 (1945). The assignee acquired a patent from the assignor who later made use of the patent. As a defense to the assignee's suit for infringement, the assignor asserted that the patent was a copy of an expired patent and therefore a part of the public domain at the time he allegedly infringed. Interpreted narrowly, the case establishes another exception to the doctrine of estoppel which arises when the patent allegedly infringed was based on a prior-expired patent. Interpreted broadly, however, the case could have been read to overrule estoppel in that all invalid patents are part of the public domain, whether they are invalid because they are copies or otherwise. The same policy that warranted another exception to the doctrine of estoppel also would seem to have warranted repudiation of the doctrine.

30. See Pope Mfg. Co. v. Gormully, 144 U.S. 224 (1892). The patentee-plaintiff licensed 
exceptions had so eroded the estoppel doctrine that the next step, complete repudiation, was a logical one. ${ }^{31}$ Consequently, in Lear, Inc. $v$. Adkins ${ }^{32}$ the Supreme Court explicitly renounced the doctrine of licensee estoppel..$^{33}$

\section{Lear, Inc. v. Adkins: The Court's Holding}

In 1953, John Adkins, an employee of Lear, agreed to grant the company a license on all ideas that he might develop during the term of his employment on a mutually satisfactory royalty basis. In 1955, he applied to the Patent Office for a patent on improvements on a gyroscope and then entered into a detailed contract with Lear concerning royalties. The contract could be terminated if the Patent Office refused to grant a patent on the "substantial claims" of Adkins' original application or if the patent issued but was subsequently held invalid. After Adkins' application had been rejected twice, Lear, believing that a patent would never be granted, notified Adkins that it would no longer pay royalties on the gyroscopes produced at Lear's Michigan plant. ${ }^{34}$ In 1960, upon narrowing his claims considerably, Adkins received a patent. After two conflicting lower court determinations, ${ }^{35}$ the California Supreme

his bicycle patent to the defendant on condition that he manufacture only certain types of bicycles and that he agree not to challenge thc validity of the plaintiff's patent. Alleging that the licensee breached the latter provision, the patentee prayed for an accounting for the machines made in violation of the agreement and for an injunction from further manufacture. The lieensee defended on the grounds of patent invalidity. See also Mercoid Corp. v. MidContinent Inv. Co., 320 U.S. 661,666 (1944).

31. In 1947 Justice Frankfurter cxclaimed: "If a doctrine that was vital law for more than ninety years will be found to have now been deprived of life, we ought at least to give it decent public burial." MacGregor v. Westinghouse Elec. \& Mfg. Co., 329 U.S. 402, 416 (1947) (dissenting). For an argument that the precedent to Lear did not point to the complete repudiation of licensee estoppel see Dodds, After Lear v. Adkins-What?, 51 J. PAT. OfF. Soc'y 621, 623-29 (1969).

32. 395 U.S. 653 (1969).

33. Automatic Radio Mfg. Co. v. Hazeltine Research, Inc., 339 U.S. 827 (1950) was the last express approval of the doctrine and was the specific case overruled in Lear.

34. Payments were continued for two more years on the gyros produced in Lear's California plant, which were apparently closer in design to the device described in Adkins' patent application, before Lear notified Adkins that it was terminating the agreement.

35. See Adkins v. Lear, Inc., 52 Cal. Rptr. 795, 801 (Ct. App. 1966). The trial court directed a verdict of $\$ 16,000$ for Adkins on the gyros manufactured in California, holding that Lear was estopped by its licensing agreement from questioning the validity of the inventor's patent. Because Lear claimed the Michigan gyros were developed independently of Adkins' invention, the trial judge directed the jury to award the inventor a recovery only if it were satisfied that the invention was novel within the meaning of the federal patent laws. The jury returned an $\$ 888,000$ verdict for Adkins, but Lear was granted judgment notwithstanding the 
Court held that the 1955 contract had not been properly terminated and consequently the doctrine of estoppel barred Lear from questioning the validity of the patent.$^{36}$ The state court also rejected Lear's contention that the Michigan gyros, as opposed to others manufactured in California, were a natural extension of the prior art and found at least partial reliance on Adkins' invention, whether or not this invention met the standards required for the issuance of a patent, and therefore reinstated the jury verdict below. ${ }^{37}$

Since interpretation of specific provisions of the licensing agreement was held to be uniquely a matter of state law the United States Supreme Court considered only the state court's reliance on the doctrine of estoppel which barred Lear from proving that the patent was invalid..$^{38}$ ln deciding the estoppel question, the Court first noted that past efforts to accommodate the common law of contracts with federal patent law had failed. ${ }^{39}$ Analyzing the "typical" licensing situation where a patent is licensed after issuance rather than while the application is pending, ${ }^{10}$ the Court found the equities of the patentee-licensor to be weak when weighed against the public's interest in the free access to ideas that are part of the public domain." The public right to the use of inventions not the subject of valid patents had to be safeguarded in spite of traditional contract law requirements. Since the licensee often is the only one with sufficient economic incentive to contest the patent's validity, the Court viewed him as the most appropriate person to champion the public interest. ${ }^{22}$ The licensor would not be unduly burdened by

verdict on the basis that Adkins' invention had been completely anticipated by prior art. Both sides appealed to the California Court of Appeals where it was held that Lear was within its contractual rights in terminating the royalty obligations in 1959 and tbat if Adkins desired to recover damages after that date he had to bring an infringement action in the federal courts. The court held further that Lear had to pay pre-1959 royalties on both the Michigan and California gyros under the contract regardless of the validity of the patent. Both parties again appealed.

36. Adkins v. Lear, Inc., 67 Cal. 2d 882, 435 P.2d 321, 64 Cal. Rptr. 545 (1967).

37. Id. at 907-15, 435 P.2d at 336-41, 64 Cal. Rptr. at 560-65.

38. 395 U.S. at $661-62$.

39. Id. at 668 .

40. Id. at 669-71.

41. Id. at 670-71. As used in this note "public domain" refers generally to those ideas in which there are no protected private interests. It has been suggested that the Lear Court's use of the phrase would not include ideas not generally known and that this use raised but did not answer the issue of state law protection of unpatented secret ideas. See Adelman \& Jaress, Inventions and the Law of Trade Secretes After Lear v. Adkins, 16 WAYNE L. Rev. 77, 8283, 85 (1969); notes 84-106 infra and accompanying text.

42. 395 U.S. at 670 . See also Brief for Petitioner at 36 . 
allowing the licensee to contest validity, the Court reasoned, since his case would be buttressed by the presumption that the Patent Office's ex parte legal conclusion of patentability was correct..$^{43}$ Consequently, in order to enable the licensee to contest validity and rid the public of worthless patents, the licensee estoppel doctrine was overruled. ${ }^{44}$

The Court then addressed itself to the particular fact situation of the Lear case where the licensing agreement was consummated four years prior to the granting of the patent..$^{45}$ Adkins' claim to royalties for the full patent term of 1960 to 1977 was rejected as overbroad. ${ }^{46}$ Applying the policy of the patent laws despite the limiting contract term, the claim to royalties until such time as the patent was held invalid as required by the 1955 agreement was also rejected by the Court. ${ }^{47}$ If the collection of royalties was allowed until an adjudication of the patent's validity, the licensor would have a strong economic incentive to use dilatory court tactics. Moreover, use of such delaying tactics might deter licensees from challenging patent validity and thereby protecting the public interest, especially in an area where extended legal proceedings could last longer than the actual useful life of a patent. The Lear decision thus makes it clear that a licensee will be permitted to avoid royalties after the issuance of the patent from the time he stops payment, provided he is successful in proving patent invalidity.99

Prior to Lear, any party with standing, other than the estopped assignor or licensee, could contest the validity of a patent. ${ }^{50}$ By looking to the policy behind the patent and antitrust laws in order

\footnotetext{
43. 35 U.S.C. § 282 (1964).

44. 395 U.S. at 671.

45. Id. at 671-75.

46. Id. at $672-73$.

47. Id. at 673-74.

48. Id.

49. Id. at 674. The Lear decision is to be retroactively applied since "the public's interest in the elimination of specious patents would be significantly prejudiced if the retroactive effect of today's decision were limitcd in any way." Id. n. 19 .

50. A party sued for patent infringement may raise the defense of invalidity. 35 U.S.C. $\S 282$ (1964). Similarly, a party being threatened or charged with infringemcnt by a patentee may seek a declaratory judgment of invalidity under 28 U.S.C. § 2201 (1964). See, e.g., Wclch v. Grindle, 251 F.2d 671-(9th Cir. 1957); Tuthill v. Wilsey, 182 F.2d 1006 (7th Cir. 1950); E.J. Brooks Co. v. Stoffel Seals Corp., 160 F. Supp. 581 (S.D.N.Y. 1958); I-T-E Circuit Breaker Co. v. McGraw Elec. Co., 121 F. Supp. 435 (E.D. Pa. 1954).
} 
to enable the licensee ${ }^{51}$ to contest validity, the Lear court reached a desirable result. Federal legislation, especially the antitrust laws, reflects an obvious disapproval of economic monopolies.52 The patent is an exception to this general rule made in order to encourage inventors to disclose their ideas for public use and thereby promote further invention by making the prior art accessible to prospective inventors. ${ }^{53}$ In effect, the government is contracting with the patentee to disclose his ideas to the public in return for a seventeen year monopoly. However, this monopoly is sanctioned by the government only if the inventor is benefiting the public with a truly novel invention. ${ }^{54}$ If the Patent Office's ex parte determination is incorrect, the patentee is granted an exclusive right to an invention when he is not entitled to one-a monopoly that is against public policy-and this exclusive right must be defeated. By enabling another litigant, frequently the onc with the strongest economic incentive, to contest patent validity, the public will more effectively be rid of these unnecessary monopolies.

When the validity of the patent is questionable, it is in the licensee's interest, as well as that of the public, to force litigation by stopping royalty payments and subjecting himself to suit by the licensor, for, if successful, the licensee would be freed from further royalties, ${ }^{55}$ and the public would be relieved of the burden of an invalid patent. If the licensee is unsuccessful, he would normally be liable only for the royalties he was already obligated to pay under the contract. However, there are sufficient factors to deter the licensee from forcing needless litigation by withholding royalties when he does not have a sound basis for asserting invalidity. The litigation expense may be great enough to assure that only truly doubtful patents will be challenged. ${ }^{56}$ Further, where a frivolous

51. Although Lear's facts are restricted to the licensing situation, an assignor will probably now be permitted to contest validity as well. See note 63 infra and accompanying text.

52. See W. Ballard, Patents and Free EnTERPRISE 1-12 (1947). See generally Sherman Act, 15 U.S.C. $\$ \S 1-7$ (1964); Clayton Act, 15 U.S.C. $\S \S 12-27$ (1964).

53. See L. AmDur, Patent Fundamentals 51-52 (1948); W. Ballard, supra note 52, at 12-13; L. Wood, Patents and antitrust Law 15-16 (1942); Staff of House Comm. on the Judiciary, 84th Cong., 2d Sess., Antitrust Problems in the Exploitation of PATENTS I (Comm. Print 1956).

54. L. Amdur, supra note 53, at 5I-52; I Deller § 31 (1964); J. Norman, Patents 18 (1853). There are other situations such as the misuse of patent power where the patent monopoly will not be sanctioned by the courts. See, e.g., B.B. Chemical Co. v. Ellis, 314 U.S. 495 (1942); Leitch Mfg. Co. v. Barber Co., 302 U.S. 458 (1938).

55. 395 U.S. at 674.

56. See Note, A Reconsideration of the Patent System as a Problem of Administrative 
attempt to escape royalties is shown, the Court may award the licensor reasonable attorney's fees. ${ }^{57}$ Moreover, although a breach of the covenant to pay royalties usually is not grounds for cancellation of the license, ${ }^{58}$ if the breach defeats the whole consideration of the agreement, as when the licensee not only stops paying royalties but also ceases manufacture under the license, the agreement may be terminated by the licensor. ${ }^{59}$ In such a case, if the patent were valid, the licensee would presumably remain liable for royalties incurred prior to the cessation, and any further attempt to manufacture the article may subject the licensee to an infringement suit. ${ }^{60}$ Consequently, although the licensee has ample incentive to contest the validity of the patent in that he may avoid further royalty payments, there is sufficient deterrence to inhibit him from bringing bad faith claims when there is no real question of validity. ${ }^{61}$

Lear holds that the obligation to pay royalties ends when the lieensee stops paying royalties after the issuance of the patent if the patent is subsequently invalidated..$^{2}$ Further, although the facts of Lear are confined to a licensing agreement, in view of the Court's compilation of assignment as well as licensing cases in developing its argument, the same policy will require that estoppel be repudiated in the assignment context. ${ }^{63}$ There are, however, several important

Law. 55 HARv. L. Rev. 950, 957, 969 (1942); Note, Gratuitous Findings of Validity: A Judicial Gift to Patentees, 61 YALE L.J. 98, 103 (1952).

57. This remedy is to be used sparingly. See Union Nat'l Bank v. Superior Steel Corp., 9 F.R.D. 117 (W.D. Pa. 1949). But when unjustified litigation is clearly shown, the remedy is available. See Phillips Petroleum Co. v. Esso Standard Oil Co., 91 F. Supp. 215 (D. Md), aff d, 185 F.2d 672 (4th Cir. 1950).

58.

It will not do to say that a forfeiture has taken place, ipso facto, by the non-payment of the stipulated royalties, and that, therefore, all handling of the patented articles by the defendant since then has been an infringement. The law does not arm one party to a contract with the power to determine in his own favor a condition of [that] kind .... Even where the contract provides that the failure to pay shall render it null and void, the defendant has a right to be heard as to the facts upon which such annulment is made to depend. Standard Dental Mfg. Co. v. National Tooth Co., 95 F. 291, 294 (C.C.E.D. Pa. 1899).

See also White v. Lee, 3 F. 222 (C.C.D. Mass. 1880).

59. See, e.g., Oscar Barnett Foundry Co. v. Crowe, 219 F. 450 (3d Cir. 1915); Ruby v. Ebsary Gypsum Co., 36 F.2d 244 (W.D.N.Y. 1929).

60. Once the license is terminated the licensee has no further patent protection. See 4 DeLler $\S 411$.

61. Besides being so proteeted from bad faith claims of invalidity, the licensor will benefit if his patent withstands the rigors of an adversary proceeding, for the contest holding it valid will strengthen the patent by making further contests of validity less likely.

62. 395 U.S. at 674.

63. Id. at $663-68$. 
questions left unanswered by the opinion. May the parties avoid the Lear result by a consent judgment? ${ }^{64}$ If payments are made after the patent is issued and before the suit contesting validity is commenced, can the licensee recoup these past royalty payments? ${ }^{65}$ Does federal patent policy bar enforcement of a contract regulating access to an unpatented or patent-pending secret idea? ${ }^{66}$

\section{Can the Parties Avoid Lear by a Consent Judgment?}

The public policy voiced in Lear supports the "full and free competition in the use of ideas which are in reality a part of the public domain." 67 Since this policy was frustrated by a judiciallycreated doctrine barring the licensee from the defense of patent invalidity, the doctrine was judicially repudiated. ${ }^{68}$ Although the remainder of the license may still be enforceable, ${ }^{69}$ a contract clause similarly prohibiting the defense of invalidity would also be void as against public policy and therefore unenforceable. ${ }^{70}$ However, does incorporation of the agreement in a consent judgment alter this

64. See notes 67-79 infra and accompanying text.

65. See notes $80-83$ infra and accompanying text.

66. See notes 84-106 infra and accompanying text.

67. 395 U.S. at 670.

68. Id. at 670-71.

69. Generally, contracts in conflict with public policy are illegal or void. See, e.g., KaiserFrazer Corp. v. Otis \& Co., 195 F.2d 838 (2d Cir.), cert. denied, 344 U.S. 856 (1952); Kalos v. Saliaris, 116 F.2d 440 (4th Cir. 1940); Coyne v. Superior Incinerator Co., 80 F.2d 844 (2d Cir. 1936). However, if an agreement based on legal consideration contains several promises, and the illegal promise may be separated, the remainder of the contract will be enforceable. See, e.g., Brown v. R.\&R. Engineering Co., 264 F.2d 219 (3d Cir. 1959); Kosuga v. Kelly, 257 F.2d 48 (7th Cir. 1958), aff d, 353 U.S. 516 (1959).

70. See Katzinger Co.v. Chicago Metallic Co., 329 U.S. 394 (1947). Here the Court stated that a contract clause not to challenge the validity of the licensor's patent could "no more overrule Congressional policy than [could] . . an implied estoppel." Id. at 401-02. Cf. Pope Mfg. Co. v. Gormully, 144 U.S. 224, 233-36 (1892). Although not explicitly reaching the question, the Lear Court pointed toward the same result. When faced with the question of whether Lear would be required to pay royalties during the time in which the patent was being challenged, the Court refused to enforce the portion of the license agreement which provided that royalties were due unțil the determination of patent invalidity. The Court stațed that

[t] the parties' contract . . . is no more controlling on this issue than is the State's

doctrine of estoppel which is also rooted in contract principles. The decisive question

is whether overriding federal policies would be significantly frustrated if licensees could

be required to continue to pay royalties during the time they are challenging patent

validity in the courts. 395 U.S. at 673.

On the theory that this provision would significantly frustrate overriding federal policies, the Court declined to enforee it. The same federal policies would seem to warrant the Court's refusal to enforce a contract provision disabling the licensee from contesting the patent's validity. 
result? In other words, if the licensor brings an infringement suit ${ }^{71}$ against the prospective licensee, or the licensee seeks a declaratory judgment ${ }^{72}$ of invalidity, in each case the validity of the patent being at issue, and the licensee promptly consents to a judgment upholding the patent's validity, should the judgment be res judicata? ${ }^{73}$

Res judicata is based on the public policy of putting an end to litigation, ${ }^{74}$ but this policy gives way if there is an overriding policy that must be honored. ${ }^{75}$ There must therefore be a balancing $:^{76}$ On one side is the policy of finalizing litigation and on the other is the public interest in permitting patent monoplies only when based on valid patents. When the judgment merely incorporates an agreement between the parties without an adversary determination of patent validity, 77 this latter policy will be frustrated by giving the consent judgement res judicata effect just as it was frustrated by licensee estoppel or by a contract provision prohibiting the licensee from contesting validity.

In weighing these policies, the Second Circuit has afforded more protection to the public interest involved in the removal of the unwarranted monopoly accorded an invalid patent. ${ }^{78}$ It has held that

\footnotetext{
71. 35 U.S.C. § 271 (1964).

72. 28 U.S.C. $\$ 2201$ (1964).

73. For a discussion of consent judgments as res judicata, see Annot., 2 A.L.R.2d 514 (1946).

74. See Restatement of JUdGMENTS $§ 1$, comment a (1942).

75. See, e.g., Mercoid Corp. v. Mid-Continent Inv. Co., 320 U.S. 661 (1944); United States v. U.S. Fidelity and Guar. Co., 309 U.S. 506 (1940); Kalb v. Feverstein, 308 U.S. 506 (1940); Keokuk \& W.R.R. v. Missouri, 152 U.S. 301 (1894); In re Di Carlo's Estate, 3 Cal. 2d 225, 44 P.2d 562 (1935); People ex rel Arkansas Valley Sugar Beet \& Irrigated Land Co. v. Burke, 72 Colo. 486, 212 P. 837 (1923). See also cases collected at Annot., 88 L. Ed. 389, 390 (1944).

76. See, e.g., Addressograph-Multigraph Corp. v. Cooper, 156 F.2d 483 (2d Cir. 1946); Pierson v. Pierson, 15 N.J. Misc. 117, 189 A. 391 (Ch. 1937). See generally Annot., 2 A.L.R.2d 514, 532 (1946).

77. Cf. Fruehauf Trailer Co. v. Gilmore, 167 F.2d 324 (10th Cir. 1948) (consent judgment not res judicata in tort action where court in first suit performed merely the administrative function of rccording the parties' agreement).

78. See Addressograph-Multigraph Corp. v. Cooper, 156 F.2d 483, 485 (2d Cir. 1946).

[O]n grounds of public policy ... in a decree entered by consent, either an adjudication of infringcment, or a grant of some relief from which infringement may be inferred, is essential before any effect of res judicata can be given to it on the issuc of validity .... [ [V] think the public intcrest in a judicial determination of the invalidity of a worthless patent is great enough to warrant the conclusion that a defendant is not estopped by a dccree of validity, at least when this decree was by consent, unless it is clear that in the litigation resulting in the decree this issue of validity was genuine. Id. at 485 .
}

But see Brunswick Corp. v. Chrysler Corp., 408 F.2d 335 (7th Cir. 1969), where the court upheld the prior consent judgment but did not consider public policy in reaching its result. 
when a prior adjudication of validity has been made through a consent decree, the defendant is not estopped by the decree unless it is clear that genuine litigation was involved in the original proceeding. ${ }^{79}$ Such an approach would seem consistent with the emphasis placed on the public interest in Lear. Indeed, to do otherwise would allow the Lear result to be avoided by ignoring the very interests it sought to protect.

May a Licensee Recoup Royalties Paid After the Issuance of the Patent and Prior to the Suit for Royalties?

Although a licensee could not contest validity prior to Lear, an alleged infringer, or a third party with standing to bring a declaratory judgment action, could assert patent invalidity. ${ }^{80}$ If the patent was held invalid in this third party suit, the licensee was normally freed from further royalty payments, since the consideration flowing to the licensee failed once the patent was proved invalid.$^{81}$ However, prior to the holding of invalidity, the contract was supported by sufficient consideration: freedom from an infringement suit and deterrence of competitors. Therefore, no recoupment of past royalties was allowed. ${ }^{82}$ This rationale should apply no matter who proves patent invalidity and effectuates the eviction. Lear merely expanded the class that may prove invalidity and therefore should not change the disallowance of recovery of past royalties.

Moreover, the policy behind Lear would be more effectively promoted by disallowing recoupment. The Lear Court enabled the licensee to contest validity in order to rid the public of needless patents. ${ }^{83}$ By denying recoupment the Court would not inhibit the licensee but would put pressure on him to test the patent's validity as soon as he has a sound basis for so doing, for until the suit is brought the licensee would be obligated to pay royalties under the

79. Addressograph-Multigraph Corp. v. Cooper, 156 F.2d 483, 485 (2d Cir. 1946).

80. See note 50 supra and accompanying text.

81. See Drackett Chem. Co. v. Chamberlain Co., 63 F.2d 853, 854 (6th Cir. 1933). See also White v. Lee, 14 F. 789 (C.C.D. Mass. 1882), where the court stated that in a suit for royalties, "a plea or answer that the patent is void, is not, of itself, a sufficient defense, but that evidence of what may be called an eviction is such a defense." Id. at 791 (emphasis added). With no "eviction" the defense of invalidity is not available so royalties must be continued. See note 17 supra and accompanying text.

82. See Drackett Chem. Co. v. Chamberlain Co., 63 F.2d 853, 854 (6th Cir. 1933).

83. 395 U.S. at $670-71$. 
contract. Recoupment of past royalties should therefore be disallowed because a contract supported by sufficient consideration would be enforced until its consideration failed and the Lear policy would be promoted.

\section{Does Federal Patent Policy Bar Enforcement of a Contract Regulating Access to an Unpatented or Patent Pending Secret Idea?}

Justice Black, concurring and dissenting in Lear, agreed with the holding of the Court but stated that it should have gone. one step further and held that licenses based on unpatentable or patent pending inventions that are later deemed unpatentable could not be enforced. ${ }^{84}$ In order to understand the issues involved in this question, a brief discussion of the patent system's relationship to the law of trade secrets is in order.

The paramount purpose of the federal patent law is "[t]o promote the progress of science..." Congress has offered the inventor a seventeen year monopoly, an exception to the antitrust laws, in exchange for disclosure of his invention. ${ }^{86}$ The inventor is free to keep his idea secret, ${ }^{87}$ but if he does so, the right to exclude others from his invention is limited to that protection afforded him by the law of trade secrets. ${ }^{88}$ An important objective of trade secret law is to protect the inventor's discovery from fraudulent disclosure. ${ }^{89} \mathrm{He}$ has a right to prohibit

\footnotetext{
84.

$[N]_{0}$ Statc has a right to authorize any kind of monopoly on what is claimed to be a new invention, except when a patent has been obtained from the Patent Office under the exacting standards of the patent laws. One who makes a discovery may, of course, keep it secret if he wishes, but private arrangements under which self-styled "inventors" do not keep their discoveries secret but rather disclose then,, in return for contractual payments, run counter to the plan of our patent laws, which tightly regulate the kind of inventions that may be protected . . . . The national policy expressed in the patent laws, favoring free competition and narrowly limiting monopoly, cannot be frustrated by private agrcements . . . . 395 U.S. at 676-77.
}

The majority opinion raised the issue but expressly reserved judgment for a future case. Id. at 674-75; see Adelman \& Jaress, supra note $4 \mathrm{I}$, at 78.

85. U.S. CoNST. art. $1, \S 8, \mathrm{cl} .8$.

86. See L. AMDUR, supra note 53, at 52.

87. Id.

88. The inventor may contract with the person to whom he discloses his invention not to disclose it to others and sue under the contract upon breach. See 12 R. MiLgrim, Business Organizations, Trade Secrets $\S \S 3.01-.05$ (1969) [hereinafter cited as Milgrim]. In the absence of a contract, he is protected by operation of law. See id. $\$ \S 4.01-.03$.

89. See Doerfer, The Limits on Trade Secret Law Imposed by Federal Patent and Antitrust 
those to whom he confidentially discloses his invention from revealing and independently using it, but he cannot exclude anyone who independently develops the device through research or by examination of the manufactured product. ${ }^{90}$ This limited protection is based on nondisclosure in contrast to the required disclosure of the patent laws, for once the invention is no longer secret, the protection ends. ${ }^{91}$ Consequently, although both state trade secret law and federal patent law promote invention, there is a conflict: Public disclosure of the invention terminates trade secret protection, while public disclosure is required to obtain patent protection.

Despite the conflict, patent and trade secret law should generally co-exist, except in the situation of the "potentially perpetual secret" where disclosure may not occur within the period protected by the patent laws. ${ }^{92}$ Congress did not intend that its patent legislation be preemptive..$^{93}$ Disclosure in return for a monopoly is the means to meet the objective of promoting science on the theory that access to other inventions will spur further discovery. ${ }^{94}$ Trade secret protection also presumably promotes invention. If an investor knew that after successfully developing his invention he would have no protection against one who fraudulently copies the device and manufactures it without the burden of development costs, the inventor would be discouraged from further efforts. Moreover trade secret law only temporarily conflicts with the means which Congress has chosen to promote invention through the patent laws, for whether the inventor

Supremacy, 80 HaRv. L. RÉv. 1432, 1435-39 (1967) [hereinafter cited as Doerfer]. See also Handler, Antitrust: 1969, 55 CORNeLL L. Rev. 161, 186-87 (1970).

90. See MiLgrim § 5.04[1].

91. Id. at § 2.03. See also Doerfer 1434-35.

92. Adelman and Jaress describe "potentially perpetual secrets" as being "usually process inventions where an examination of the resulting product does not disclose the method of manufacture, or chemical formulations whose composition cannot be analyzed." Adelman \& Jaress, supra note $4 \mathrm{I}$, at 92 . A patent will not be issued when the invention is put to public use for more than a year prior to the patent application. 35 U.S.C. $\S 102(b)$ (1964). Therefore, it has been suggested that state trade secret law protection of "potentially perpetual secrets" should be limited to the one year period. Adelman, Trade Secrets and Federal PreEmption-The Aftermath of Sears and Compco, 49 J. Pat. OfF. Soc'y 713, 729-32 (1967). It might be suggested, however, that the decisional standards of what constitutes a "potentially perpetual secret" will involve both state and federal courts in impossible technicalities and may lead to the abandonment of trade secret law. Alternatively, it may be argued that these "potentially perpetual secrets" rarely ripen into perpetual secrets and should be tolerated without the abandonment of trade secret law. $C f$. Doerfer 1448.

93. See Note, The Stiffel Doctrine and the Law of Trade Secrets, 62 Nw. U.L. REv. 956, 964-66 (1968).

94. See Doerfer 1440-41. 
relies exclusively on trade secret protection or whether he uses it only during the patent pending period, the conflict will soon be resolved: Disclosure will usually be accomplished in the former situation by commercialization ${ }^{95}$ and in the latter by the issuance of the patent.

When an inventor licenses his invention but relies exclusively on trade secret protection, or relies on such protection while his patent application is pending, would enforcement of his contract frustrate the policy of the patent and antitrust laws? The refusal of the Lear Court to answer that question precipitated the concurrence by Justice Black. ${ }^{96} \mathrm{He}$ argued that enforcement of a contract calling for royalties on the invention while a patent is pending would indeed frustrate federal policies if the invention is later deemed unpatentable, and that by enforcing such agreements the state was illegitimately ereating a monopoly. ${ }^{97}$ To support his proposition he cited Sears, Roebuck \& Co. v. Stiffel Co..$^{98}$ and Compco Corp. v. Day-Brite Lighting Co ${ }^{99}$ in which an Illinois unfair competition law prohibiting a manufacturer from copying an unpatentable device was held to be preempted by the federal patent law. While it is true that the state's action in denying an independent manufacturer the opportunity to copy an unpatentable article by its unfair competition law-thereby granting an exclusive right to an invention to the inventor though he did not have a patent-must be overturned, it does not follow that all licenses of unpatentable or patent pending inventions are unenforceable.

By enforcing a contract based on an unpatented or patent pending invention, state law is not creating a monopoly in contravention of the patent laws since the licensee, under the common law of trade secrets, does not aequire the protection of the patent laws or its equivalent. Trade secret law provides that if a

95. See Adelman \& Jaress, supra note 41, at 91-92. The exception to this position, however, is the "potentially perpetual secret." See note 92 supra and accompanying text.

96. 395 U.S. at 676-77. The majority of the Court held that the state court had not satisfactorily passed on the issue as yet so it decided to reserve the question for later determination. Id. at 674-75. Justice White, in a concurring opinion, reasoned that the Court should not pass on the issue since: (1) if the patent were determined valid on remand, the issue would be moot, (2) if the patent were held invalid and the state had a chance to pass on the issue it might accommodate federal and state law so as to dispense with the need for further review, and (3) the parties had not briefed or prepared the issue adequately. Id. at 682 .

97. Id. at 677.

98. 376 U.S. 225 (1964).

99. 376 U.S. 234 (1964). For a recent discussion of Sears, Compco, and related trade secret decisions, see Adelman \& Jaress, supra note 41, at 80-84. 
member of the public develops the same device through independent research, such person is not prohibited from exploiting it. ${ }^{100}$ If a member of the public can, under these circumstances, exploit the invention there is no monopoly, and the contract should be enforced. ${ }^{101}$ Moreover, by enforcing such contracts, the courts would be furthering the policy of the federal patent laws-promotion of invention-for there is a greater economic incentive for an inventor to produce when he is assured that his discovery, even if not patentable, may be licensed for profit. There is a need for such incentive, for unpatentable, as well as patentable inventions, "promote the progress of science," and the former do not involve the grant of a legal monopoly.

Though not creating a monopoly, it is possible that state law enforcement of these licenses may create an unreasonable restraint of trade. ${ }^{102}$ If the restrictive convenants are not too broad ${ }^{103}$ and are necessary to accomplish a legitimate business purpose it is unlikely that there will be antitrust problems. ${ }^{104} \mathrm{~A}$ covenant not to disclose the invention qualifies as a necessary restriction ${ }^{105}$ since once the invention is disclosed, trade secret protection terminates and the underlying discovery becomes accessible to the public in general. Moreover, despite the disclosure restriction, unpatented and patent pending licenses promote invention by giving the inventor a "head start" toward recouping research and development costs. ${ }^{106}$ Although there may be some restraint on trade by the disclosure

100. See MiLGrim $§ 5.04[1]$.

101. See United States v. E.1. du Pont de Nemours \& Co., 353 U.S. 586, 593 (1957) (quoting Transamerica Corp. v. Board of Governors, 206 F.2d 163, 169 (3d Cir. 1953)). An lllinois law of unfair competition gave the holders of the trade secrets in Stiffel and Compco the power "to prevent the copying of an article which represents too slight an advance to be patented . . . Sears, Roebuck \& Co. v. Stiffel Co., 376 U.S. 225, 231-32 (1964). When the holder of the trade secret does not have this power to exclude competitors from his secret at will, no monopoly results.

102. See R. Callmann, The Law of Unfair Competition, Trademarks and MONOPOLIES $§ 57(\mathrm{c})$ (3d ed. 1968).

103. For an example of an agreement that was held to be too broad, see United Statcs v. National Lead Co., 63 F. Supp. 513 (S.D.N.Y. 1945), affd. 332 U.S. 319 (1947).

104. See R. CallmanN, supra note 102 , at $\$ 57(\mathrm{c})$.

105. "[S]o far as these contracts limit the communication of what the [inventor] might have refrained from communicating to anyone, there is no monopoly . . . and no contract in restraint of trade, either under the [Sherman Act] or at common law." Board of Trade v. Christie Grain \& Stock Co., 198 U.S. 236, 252 (1905). But see Associated Press v. United States, 326 U.S. 1, 15-16 n.14 (1945).

106. See 395 U.S. at 682 n.2 (White, J., concurring); Adelman \& Jaress, supra note 41, at 88-91; Doerfer 1451. 
restriction, this minimal restraint should not be held to be unreasonable since the restraint is necessary to effectuate a licensing agreement in furtherance of a legitimate business purpose which promotes invention.

Therefore, trade secret law, in general, and licenses of unpatented and patent pending inventions in particular, stimulate invention, the primary purpose of the patent law, and this stimulation outweighs the non-disclosure and minimal restraints on trade brought about by trade secret law and licensing agreements under its sole protection. Consequently, the Lear holding should not be extended as proposed by Justice Black, but patent and trade secret law should co-exist through enforcement of non-patent and patent pending licenses.

\section{CONCLUSION}

Lear broadly represents an attempt to strictly circumscribe the existence of lawful patent monopolies. The legal right to invalidate a patent has been given to the party with the greatest economic interest in its elimination. The licensee who has developed a sophisticated marketing system and can absorb the costs of litigation will not hesitate to challenge voidable patents, because he can immediately realize a profit free of royalty costs. This incentive of economic self-interest should not be frustrated through devices such as consent judgments or by royalty recoupment; otherwise "the public ... [will] continually be required to pay tribute to would-be monopolists without need or justification." 107 Nevertheless, post-Lear patent policy should not bar the enforcement of contracts regulating access to unpatented or patent pending secret ideas and thereby lead to the demise of state trade secret law.

107. 395 U.S. at 670. 
